\title{
EVALUASI ATRIBUT KESEDERHANAAN, KETEPATAN WAKTU DAN STABILITAS PADA SURVEILANS KESEHATAN HAJI
}

\author{
Riva Noviyanti \\ Departemen Epidemiologi Fakultas Kesehatan Masyarakat Universitas Airlangga \\ Surabaya, Jawa Timur, Indonesia \\ Alamat Korespondensi : \\ Riva Noviyanti \\ Email: noviriva@gmail.com
}

\begin{abstract}
Every year, the Indonesian pilgrims reached 200 thousand people and the health risks were still high. Hajj health surveillance are conducted to determine the progression of the disease in terms of place and time in pilgrims, and used for prevention efforts. The purpose of this research was to evaluate the attributes of surveilance performed by Dinkes Kota Surabaya in 2015. The research was done in Dinkes Kota Surabaya. This research was descriptive and its implementation using interview techniques using an instrument such as a questionnaire sheet. Respondents were a managing officer of health surveillance program Hajj in Dinkes Kota Surabaya and at Puskesmas. Results from this study is the evaluation of the attributes of surveillance shows that health Hajj surveillance systems in Dinkes Kota Surabaya in 2015 already meet the attributes of flexibility, timeliness, sensitivity, representativeness and acceptability. The evaluation of the attributes of surveillance is not fulfilled on health Hajj surveillance systems in Dinkes Kota Surabaya are attributes of simplicity, data quality and stability, while the positive predictive value can not be calculated. Advice that can be given are making plans a schedule for examining prospective pilgrims, monitoring the reporting and increasing the number of surveillance personnel.
\end{abstract}

Keywords: evaluation, atribute of surveillance, health hajj surveillance

\begin{abstract}
ABSTRAK
Setiap tahunnya jemaah haji Indonesia mencapai 200 ribu orang lebih, dengan risiko kesehatan yang masih tinggi. Surveilans kesehatan haji dilaksanakan untuk mengetahui perkembangan penyakit menurut tempat dan waktu pada jemaah haji dan dimanfaatkan untuk upaya penanggulangan. Tujuan penelitian ini untuk melakukan evaluasi atribut surveilans kesehatan haji di Dinas Kesehatan (Dinkes) Kota Surabaya. Lokasi penelitian adalah Dinkes Kota Surabaya. Penelitian deskriptif ini dilaksanakan dengan wawancara menggunakan instrumen berupa lembar kuesioner. Responden adalah petugas program surveilans kesehatan haji di Dinkes Kota Surabaya dan di Puskesmas. Hasil dari penelitian ini menunjukan bahwa sistem surveilans kesehatan haji di Dinkes Kota Surabaya tahun 2015 sudah memenuhi atribut fleksibilitas, ketepatan waktu, sensitivitas, kerepresentatifan dan akseptabilitas. Atribut surveilans kesehatan haji di Dinkes Kota Surabaya yang belum terpenuhi yaitu atribut kesederhanaan, kualitas data dan stabilitas, sedangkan nilai prediktif positif tidak dapat dilakukan perhitungan. Disaran diberikan adalah membuat rencana pemeriksaan calon jemaah haji dan dilakukan pemantauan laporan serta penambahan jumlah tenaga surveilans terlatih.
\end{abstract}

Kata kunci: evaluasi, atribut surveilans, surveilans kesehatan haji

\section{PENDAHULUAN}

Penyelenggaraan kesehatan haji merupakan rangkaian kegiatan pelayanan kesehatan haji yang meliputi pemeriksaan kesehatan, bimbingan dan penyuluhan kesehatan haji, pelayanan kesehatan, imunisasi, surveilans, Sistem Kewaspadaan Dini dan Respon (SKDR) dan respon KLB, 
penanggulangan KLB dan musibah massal, kesehatan lingkungan dan manajemen penyelenggaraan kesehatan haji (Keputusan Menteri Kesehatan Republik Indonesia No. 442 Tahun 2009).

Berdasarkan data Dinkes Provinsi Jawa Timur, jumlah jemaah haji sebanyak 222.096 (tahun 2010) meningkat pada sebanyak 222.560 (tahun 2011) dan menurun sebanyak 212.111 (tahun 2012). Jumlah jemaah risiko tinggi pada tahun 2010 hingga 2012 mengalami peningkatan. Persentase jemaah haji risiko tinggi pada tahun 2010 adalah $39,4 \%$ (tahun 2010), meningkat menjadi 45,9\% (tahun 2011) dan 71,41\% (tahun 2012). Sedangkan jemaah haji Provinsi Jawa Timur pada tahun 2013 sebanyak 27.357 jemaah dan sebanyak $48 \%$ jemaah memiliki kondisi risiko tinggi.

Jemaah haji kota Surabaya pada tiga tahun terakhir mengalami peningkatan, sebanyak 1.331 (tahun 2013), sebanyak 1.558 (tahun 2014) dan sebanyak 2.235 (tahun 2015). Peningkatan jumlah jemaah haji berbanding lurus dengan peningkatan jumlah jemaah haji risiko tinggi. Jemaah haji dengan status risiko tinggi sebanyak $61,6 \%$ (tahun 2013), meningkat sebanyak 73,3\% (tahun 2014), dan 96,2\% (tahun 2015).

Berdasarkan uraian diatas, jumlah jemaah haji risiko tinggi dari tahun 2013 hingga 2015 meningkat sehingga evaluasi atribut surveilans terhadap pelaksanaan surveilans kesehatan haji di Dinkes Surabaya perlu dilakukan untuk pengambilan keputusan dan penanggulangan secara cepat. Tujuan penelitian secara umum adalah mengevaluasi sistem surveilans kesehatan haji di Dinkes Kota Surabaya tahun 2015 berdasarkan atribut surveilans.

\section{METODE PENELITIAN}

Penelitian deskriptif ini merupakan penelitian evaluasi untuk menilai suatu program yang sedang atau telah berjalan sehingga dapat digunakan untuk perbaikan dan atau peningkatan program tersebut. Penelitian ini dilakukan di Dinkes Kota
Surabaya pada April hingga Juni 2016. Responden sebanyak 13 orang yang terdiri dari 1 koordinator pelaksana surveians kesehatan haji di Dinkes Kota Surabaya dan 12 orang petugas surveilans kesehatan haji di Puskesmas. Puskesmas yang dipilih menggunakan teknik multi stage cluster sampling (Nazir, 1988), yaitu Puskesmas Mulyorejo, Puskesmas Pucang Sewu, Puskesmas Tambakrejo dan Puskesmas Sidotopo Wetan. Setiap puskesmas terdapat tiga orang responden. Teknik pengumpulan data diperoleh melalui wawancara dengan menggunakan instrumen kuesioner. Analisis dilakukan secara deskriptif dengan metode content analysis yaitu hasil yang diperoleh dibandingkan dengan teori yang ada secara narasi.

\section{HASIL}

\section{Gambaran Kesehatan Haji di Dinkes Kota Surabaya}

Kesehatan haji di Dinkes Kota Surabaya menunjukkan bahwa jumlah jemaah haji diperiksa pada tahap pertama sebanyak 2178 orang dan pada pemeriksaan tahap kedua sebanyak 2152 orang. Jumlah jemaah haji yang diperiksa terbanyak terdapat di Puskesmas Dupak sebanyak 178 orang. Berdasarkan jenis kelamin, jemaah haji kota Surabaya didominasi oleh jemaah haji wanita sebesar 53\%, sedangkan berdasarkan usia jemaah haji Kota Surabaya didominasi oleh jemaah berusia 50-59 tahun yaitu sebanyak 830 orang.

Jumlah jemaah haji Kota Surabaya yang mengalami risiko tinggi pada pemeriksaan tahap pertama sebanyak 1597 orang dan didominasi oleh jemaah usia kurang dari 60 tahun dan memiliki penyakit. Pada pemeriksaan tahap kedua jumlah jemaah haji yang memiliki risiko tinggi sebanyak 1537 orang dan didominasi oleh jemaah haji kurang dari 60 tahun dan memiliki penyakit.

Berdasarkan tabel 1 penyakit terbanyak yang diderita oleh jemaah haji Kota Surabaya adalah Disorders of lipoprotein metabolism and other lipidaemias, misalnya hiperkolesterol yaitu sebanyak 467 orang. 
Tabel 1. Penyakit terbanyak yang diderita jemaah haji Kota Surabaya tahun 2015

\begin{tabular}{|c|c|c|c|c|}
\hline $\begin{array}{l}\text { Rang } \\
\text { king }\end{array}$ & $\begin{array}{l}\text { Kode } \\
\text { ICDX }\end{array}$ & Penyakit & $\begin{array}{l}\text { Jumlah } \\
\text { Kasus }\end{array}$ & $\begin{array}{c}\text { Persen } \\
\text { tase } \\
(\%)\end{array}$ \\
\hline 1 & E78 & $\begin{array}{l}\text { Disorders of } \\
\text { lipoprotein } \\
\text { metabolism and } \\
\text { other lipidaemias }\end{array}$ & 467 & 21,8 \\
\hline 2 & $\mathrm{I} 10$ & $\begin{array}{l}\text { Hypertensive } \\
\text { disease }\end{array}$ & 440 & 20,6 \\
\hline 3 & R54 & Senility & 350 & 16,4 \\
\hline 4 & E11 & $\begin{array}{l}\text { Non-insulin- } \\
\text { dependent } \\
\text { diabetes } \\
\text { mellitus }\end{array}$ & 271 & 12,7 \\
\hline 5 & E66 & Obesity & 121 & 5,7 \\
\hline 6 & E78.5 & $\begin{array}{l}\text { Hyperlipidaemia, } \\
\text { unspecified }\end{array}$ & 106 & 4,9 \\
\hline 7 & N39 & $\begin{array}{l}\text { Other disorders } \\
\text { of urinary } \\
\text { system }\end{array}$ & 64 & 2,9 \\
\hline 8 & I51.7 & Cardiomegaly & 58 & 2,7 \\
\hline 9 & M06 & $\begin{array}{l}\text { Other } \\
\text { rheumatoid } \\
\text { arthhritis }\end{array}$ & 56 & 2,6 \\
\hline
\end{tabular}

\section{Gambaran Sistem Surveilans Kesehatan Haji di Dinkes Kota Surabaya}

Sistem surveilans kesehatan haji di Dinkes Kota Surabaya terdiri dari input, proses, dan output. Input terdiri dari data dan sumber daya yang ada dalam sistem surveilans kesehatan haji. Sumber data yang digunakan oleh Dinkes Kota Surabaya adalah data Siskohatkes. Data yang ada di siskohatkes merupakan data yang terintegrasi mulai dari identitas jemaah haji diisi oleh kemenag, pelunasan diisi oleh bank, data kesehatan diisi oleh puskesmas dan Kantor Kesehatan Pelabuhan.

Jenis data surveilans kesehatan haji untuk dilaporkan melalui siskohatkes adalah data pemeriksaan kesehatan tahap pertama dan pemeriksaan kesehatan tahap kedua. Jenis data pemeriksaan tahap pertama yang dikumpulkan meliputi identitas, riwayat kesehatan (anamnesis), pemeriksaan fisik, pemeriksaan penunjang, penilaian kemandirian dan tes kebugaran. Jenis data pada pemeriksaan tahap kedua diantaranya data riwayat kesehatan, kategori risti dan data status kesehatan.

Sumber daya manusia dari surveilans kesehatan haji di Dinkes Kota Surabaya terdiri dari koordinator surveilans kesehatan haji oleh Dinkes Kota Surabaya dan petugas surveilans kesehatan haji di Puskesmas. Petugas surveilans kesehatan haji di puskesmas merupakan tim yang dibentuk Puskesmas terdiri dari 5-7 orang. Pelaksana surveilans kesehatan haji di Puskesmas memiliki tugas yang rangkap, bukan hanya menjadi petugas surveilans kesehatan haji namun juga sebagai dokter atau perawat atau pelaksana surveilans lain. Pelaksana surveilans kesehatan haji di puskesmas pernah mendapatkan sosialisasi mengenai siskohatkes.

Sumber dana yang digunakan untuk kegiatan surveilans kesehatan haji di Kota Surabaya adalah berasal dari dana Anggaran Pendapatan Belanja Daerah (APBD). Dana tersebut telah mencukupi untuk kegiatan surveilans kesehatan haji.

Proses terdiri dari pengumpulan data, kompilasi data, analisis dan interpretasi data, diseminasi informasi dan feedback. Pengumpulan data dilakukan oleh petugas yang ada di puskesmas. Pengumpulan data yang dilakukan oleh puskesmas telah mampu dilakukan dengan baik dari segi kelengkapan data. Kompilasi data telah dilakukan oleh petugas surveilans di puskesmas dan Dinkes Kota Surabaya dengan mengelompokkan data menggunakan komputer.

Analisis data oleh Dinkes Kota Surabaya dilakukan oleh tim surveilans kesehatan haji. Analisis data yang dilakukan menggunakan beberapa variabel sudah sesuai dengan kebutuhan. Variabel yang dibutuhkan meliputi proporsi jemaah haji berdasarkan jenis kelamin, usia, status kesehatan, kondisi risti, dan penyakit 10 terbanyak. Hasil dari analisis data dibuat dalam bentuk tabel dan 
grafik. Interpretasi data dilakukan dalam bentuk deskripsi.

Diseminasi (penyebaran) informasi yang dilakukan oleh puskesmas melalui web siskohatkes. Diseminasi informasi oleh Dinkes Kota Surabaya berupa laporan secara tertulis kepada atasan yaitu kepala Dinkes Kota Surabaya dan walikota Surabaya. Feedback dilakukan oleh Dinkes Kota Surabaya kepada puskesmas berupa pertemuan evaluasi.

Output sistem surveilans kesehatan haji di Dinkes Kota Surabaya menghasilkan informasi epidemiologi berupa proporsi jemaah haji berdasarkan jenis kelamin, usia, status kesehatan, kondisi risti, dan penyakit 10 terbanyak. Informasi epidemiologi tersebut dalam bentuk laporan.

\section{Atribut Surveilans Kesehatan Haji di DinkesKota Surabaya \\ Kesederhanaan}

Atribut kesederhanaan dinilai dari sebuah sistem surveilans, terdapat beberapa indikator yang terkait diantaranya yaitu kemudahan penerapan definisi operasional jemaah haji risiko tinggi, tingkat kesulitan dalam pengisian format laporan dan alur pelaporan.

Atribut kesederhanaan dilihat dari aspek definisi operasional dari jemaah haji risiko tinggi, menurut $100 \%$ dari 13 responden mudah untuk diterapkan. Berdasarkan hasil wawancara, responden menyatakan bahwa dalam pengisian format laporan yang diberikan dalam pelaksanaannya mudah untuk dilakukan sebesar 76,92\%. Hal ini disebabkan karena data diisikan sudah sesuai dengan yang dimasukkan ke siskohatkes. Sistem pelaporan yang ada sekarang sebagian menyatakan sederhana dalam pengaplikasiannya yaitu sebesar $30,76 \%$, namun ada yang menyatakan bahwa sistem pelaporannya tidak sederhana yaitu sebesar 69,23\% karena belum terbiasa dengan sistem aplikasi yang baru dan pencatatan dilakukan dua kali yaitu dengan tertulis di kertas dan di aplikasi siskohatkes.
Tabel 2. Rekapitulasi Jawaban Kuesioner Responden pada Atribut Kesederhanaan

\begin{tabular}{lcc}
\hline \multicolumn{1}{c}{ Jawaban } & Frekuensi & $\begin{array}{c}\text { Persentase } \\
(\%)\end{array}$ \\
\hline $\begin{array}{l}\text { Kemudahan } \\
\text { Penerapan definisi } \\
\text { operasional risiko }\end{array}$ & & \\
tinggi & & \\
a. Ya & 13 & 100 \\
b. Tidak & 0 & 0 \\
\hline Pengisisan format & & \\
laporan & & \\
a. Sulit & 3 & 23,07 \\
b. mudah & 10 & 76,92 \\
\hline alur pelaporan & & \\
a. Sederhana & & \\
b. Tidak & 4 & 30,76 \\
Sederhana & 9 & 69,23 \\
\hline
\end{tabular}

Atribut kesederhanaan dilihat dari aspek definisi operasional dari jemaah haji risiko tinggi, menurut $100 \%$ dari 13 responden mudah untuk diterapkan. Berdasarkan hasil wawancara, responden menyatakan bahwa dalam pengisian format laporan yang diberikan dalam pelaksanaannya mudah untuk dilakukan sebesar 76,92\%. Hal ini disebabkan karena data diisikan sudah sesuai dengan yang dimasukkan ke siskohatkes, sedangkan sistem pelaporan yang ada sekarang sebagian menyatakan sederhana dalam pengaplikasiannya yaitu sebesar $30,76 \%$, namun ada yang menyatakan bahwa sistem pelaporannya tidak sederhana yaitu sebesar 69,23\% karena belum terbiasa dengan sistem aplikasi yang baru dan pencatatan dilakukan dua kali yaitu dengan tertulis di kertas dan di aplikasi siskohatkes.

Dapat disimpulkan bahwa hasil penilaian atribut kesederhanaan dalam pelaksanaan surveilans kesehatan haji di Dinkes Kota Surabaya adalah belum memenuhi atribut kesederhanaan karena sistem pelaporan masih dirasakan tidak sederhana. 
Tabel 3. Rekapitulasi Jawaban Kuesioner pada atribut fleksibilitas oleh responden

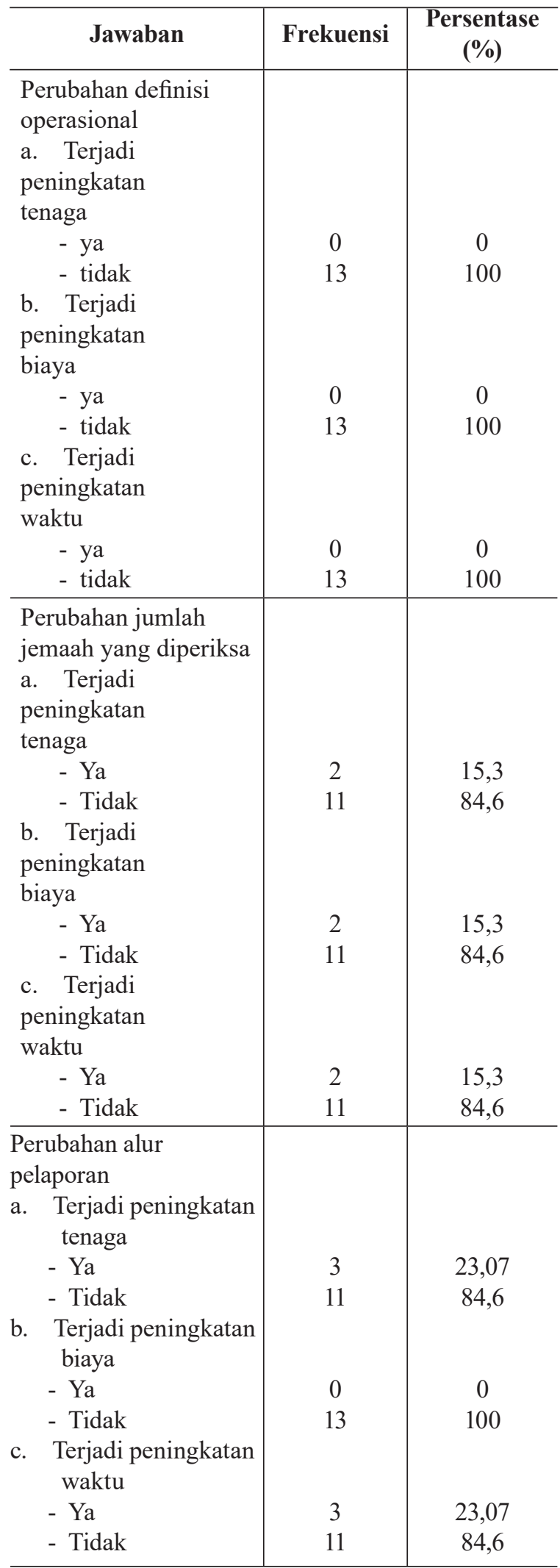

\section{Fleksibilitas}

Sistem surveilans kesehatan haji secara umum mengalami perubahan. Perubahan tersebut diantaranya definisi operasional jemaah haji risiko tinggi (risti), populasi jemaah haji yang diperiksa dan alur pelaporan. Hasil rekapitulasi jawaban kuesioner pada atribut fleksibilitas oleh responden dapat dilihat pada tabel 3 .

Perubahan definisi operasional pada sistem surveilans kesehatan haji di Dinkes Kota Surabaya tahun 2015 tidak menyebabkan peningkatan terhadap tenaga, biaya dan waktu karena pemeriksaan yang dilakukan pada jemaah dari tahun sebelumnya tidak berubah.

Perubahan jumlah jemaaah haji yang diperiksa dan perubahan alur pelaporan menyebabkan peningkatan tenaga yang dibutuhkan yaitu penambahan jumlah tenaga pemeriksa dan tenaga IT untuk memasukan data ke siskohatkes. Adanya peningkatan jumlah jemaah yang diperiksa juga menyebabkan peningkatan biaya yang dikeluarkan.

Sistem surveilans kesehatan haji tahun 2015 di Dinkes Kota Surabaya sudah fleksibel dalam menyesuaikan dengan perubahan. Perubahan ini menyebabkan tidak terjadi peningkatan terhadap tenaga, biaya dan waktu.

\section{Ketepatan Waktu}

Pemeriksaan kesehatan haji tahap pertama dimulai tiga bulan sebelum keberangkatan dan pemeriksaan kesehatan tahap kedua dilaksanakan satu bulan sebelum keberangkatan. Hasil pemeriksaan pada tahap pertama dan kedua oleh puskesmas yang masuk dan dimasukkan ke aplikasi siskohatkes setiap setelah pemeriksaan selesai dilakukan. Pelaporan data dilakukan sewaktu waktu atau sesegera mungkin setelah pemeriksaan kesehatan selesai dilakukan. Berdasarkan data di Dinkes Kota Surabaya, pelaporan yang dilakukan puskesmas sebelum 3 minggu sebelum embarkasi berjumlah 1949 jemaah haji dan 
177 jemaah haji dilaporkan setelah 3 minggu sebelum embarkasi, sehingga ketepatan waktu pelaporan di Dinkes Kota Surabaya adalah sebesar 91,6 \%. Dapat disimpulkan bahwa surveilans kesehatan haji di Dinkes Kota Surabaya sudah memenuhi target ketepatan waktu pelaporan yaitu lebih dari $80 \%$.

\section{Sensitivitas}

Berdasarkan data Dinkes Kota Surabaya tahun 2015 jemaah haji dengan risiko tinggi sebanyak 1597 orang pada pemeriksaan pertama dan 1568 orang memiliki penyakit. Pada pemeriksaan tahap kedua jemaah haji dengan risiko tinggi sebanyak 1537 orang dan 1526 orang memiliki penyakit. Dapat disimpulkan bahwa sistem surveilans kesehatan haji tahun 2015 di Dinkes Kota Surabaya sudah sensitif dalam mendeteksi jemaah haji risiko tinggi.

\section{Kualitas Data}

Atribut kualitas data dalam sistem surveilans kesehatan haji belum terpenuhi. Data yang masuk dinyatakan lengkap dan terjamin kualitasnya karena data yang diperoleh benar-benar diambil dari calon jemaah haji dan dilaporkan setelah pemeriksaan ke aplikasi siskohatkes.

"Namun kevalidan data sulit untuk diukur karena masih adanya kasus yang tidak termonitor misalnya wanita usia subur yang hamil lolos dalam pemeriksaan" (Responden 1).

\section{Akseptabilitas}

Sistem surveilans kesehatan haji di Dinkes Kota Surabaya sudah dimanfaatkan oleh institusi diluar sistem. Institusi yang memanfaatkan diantaranya adalah Kantor Kesehatan Pelabuhan dan Kementerian Agama dengan mengakses web siskohatkes.

\section{Nilai Prediktif Positif}

Berdasarkan data Dinkes Kota Surabaya jumlah jemaah haji risiko tinggi Kota Surabaya pada tahap pertama sebanyak
1597 dan sebanyak 1537 jemaah risiko tinggi pada tahap kedua. Namun, data mengenai jemaah haji risiko tinggi yang benar-benar risti tidak ada. Sehingga perhitungan nilai prediktif positif tidak dapat dilakukan.

\section{Kerepresentatifan}

Laporan kegiatan surveilans kesehatan haji dan karakteristik jemaah haji sudah sesuai dengan keadaan pada jemaah haji dengan menggambarkan orang dan tempat pada jemaah haji. Dalam laporan kegiatan sistem surveilans kesehatan haji karakteristik orang digambarkan dengan kelompok jenis kelamin yaitu jemaah haji laki-laki sebesar $47 \%$ dan jemaah haji perempuan sebesar $53 \%$. Karakteristik orang yang digambarkan kelompok umur adalah 0,13\% (kurang dari 19 tahun), 2,11\% (20-29 tahun), 7,89\% (3039 tahun), 27,82\% (40-49 tahun), 38,10\% (50-59 tahun), dan 23,92\% (lebih dari 60 tahun). Karakteristik berdasarkan tempat adalah tempat pemeriksaan dilakukan diseluruh puskesmas di Kota Surabaya. Sistem surveilans kesehatan haji di Dinkes Kota Surabaya sudah memenuhi atribut kerepresentatifan.

\section{Stabilitas}

Peralatan yang digunakan dalam sistem surveilans kesehatan haji adalah dengan menggunakan komputer kemudian dikirim menggunakan elektromedia dengan aplikasi siskohatkes. Waktu yang dibutuhkan untuk pengumpulan dan penerimaan data surveilans kesehatan haji adalah 5-6 bulan. Waktu tersebut digunakan untuk pemeriksaan tahap pertama, kegiatan posbindu dan pemeriksaan tahap kedua.

"Waktu yang dibutuhkan dalam melakukan pengaturan terhadap data seperti mentransfer atau memindahkan, memasukkan, mengedit, menyimpan dan mem-back up adalah 30 sampai 40 menit tiap satu jemaah haji. Waktu yang dibutuhkan untuk mencetak atau menghasilkan data dari siskohatkes selama 10 menit, jika terdapat kerusakan pada komputer maupun aplikasi siskohatkes tiap koordinator surveilans 
kesehatan haji di puskesmas memiliki back up data secara tertulis" (Responden 1).

Aplikasi siskohatkes pada awal penggunaan pernah mengalami masalah tidak dapat diakses selama 2 minggu karena terdapat masalah di server. Penggunaan aplikasi siskohatkes sebelumnya petugas surveilans kesehatan haji mendapatkan sosialisasi yang diselenggarakan oleh Dinkes Kota Surabaya.

\section{PEMBAHASAN}

\section{Evaluasi Sistem Surveilans Kesehatan Haji di DinkesKota Surabaya Tahun 2015 berdasarkan Atribut Kesederhanaan}

Dalam menilai atribut kesederhanaan dilihat dari kemudahan melakukan sesuai petunjuknya, kemudahan dalam pengisian format laporan dan kesederhanaan dalam alur pelaporan. Berdasarkan hasil penelitian, sistem surveilans kesehatan haji di Dinkes Kota Surabaya tahun 2015 telah ditemukan pengertian untuk pemeriksaan jemaah haji risiko tinggi pada sistem surveilans kesehatan haji di Dinkes Kota Surabaya sederhana dan mudah diterapkan. Petugas pemeriksa memiliki kemampuan dalam pemeriksaan kesehatan dan pemeriksaan yang dilakukan cukup detail sehingga dapat mendeteksi jemaah yang risiko tinggi. Definisi jemaah haji risiko tinggi telah sesuai dengan format yang diperlukan siskohatkes sehingga memudahkan dalam menentukan kriteria risti.

Sumber data sistem surveilans kesehatan haji mengenai risiko tinggi berasal dari pemeriksaan tahap pertama dan kedua yang dilakukan di Puskesmas dan dimasukkan kedalam aplikasi siskohatkes. Dalam penggunaan aplikasi siskohatkes sebelumnya dilakukan pelatihan di Dinkes Kota Surabaya sehingga memudahkan dalam memasukan data.

Pelatihan adalah keseluruhan kegiatan untuk memberi, memperoleh, meningkatkan, serta mengembangkan kompetensi kerja, produktivitas disiplin, sikap, dan etos kerja pada tingkat keterampilan dan keahlian tertentu sesuai dengan jenjang dan kualifikasi jabatan atau pekerjaan (Peraturan Menteri Tenaga Kerja dan Transmigrasi Republik Indonesia No.8 Tahun 2014). Jadi, dengan pelatihan yang sudah diterima oleh responden menyebabkan pengumpulan data menjadi lebih mudah.

Berdasarkan hasil penelitian, Jenis data pemeriksaan tahap pertama yang dikumpulkan meliputi identitas, riwayat kesehatan (anamnesis), pemeriksaan fisik, pemeriksaan penunjang, penilaian kemandirian dan tes kebugaran. Jenis data pada pemeriksaan tahap kedua adalah data riwayat kesehatan, kategori risti dan data status kesehatan. Hal ini sudah sesuai dengan Pedoman Teknis Pemeriksaan Kesehatan Jemaah Haji (2011), yaitu pemeriksaan kesehatan dilakukan sesuai protokol standar profesi kedokteran meliputi pemeriksaan medis dasar yaitu anamnesis, pemeriksaan fisik, pemeriksaan penunjang, penilaian kemandirian dan tes kebugaran. Pemeriksaan kesehatan di Puskesmas seluruhnya dilakukan oleh dokter dan perawat yang memiliki standar profesi kedokteran.

Alur pelaporan dalam sistem surveilans kesehatan haji tahun 2015 telah menggunakan sistem aplikasi siskohatkes. Aplikasi siskohatkes pelaporan data, kompilasi data, analisis dan interpretasi data lebih mudah, langsung, cepat dan tidak berbelit dan dilakukan dalam satu aplikasi, meski responden masih merasa belum sederhana.

Kesederhanaan suatu sistem surveilans dapat dilihat dari struktur yang sederhana dan mudah untuk dioperasikan. Suatu sistem surveilans harus se-sederhana mungkin, tetapi dapat mencapai tujuan. Gambaran alur informasi dalam sistem surveilans dapat menolong untuk menilai kesederhanaan (Noor, 2008). Oleh karena itu, sistem surveilans kesehatan haji di Dinkes Kota Surabaya belum memilki sifat kesederhanaan. 


\section{Evaluasi Sistem Surveilans Kesehatan Haji di Dinkes Kota Surabaya Tahun 2015 berdasarkan Atribut Ketepatan Waktu}

Hasil dari sistem surveilans kesehatan haji di Dinkes Kota Surabaya tahun 2015 mengenai atribut ketepatan waktu dapat dilihat dari beberapa hal berikut ini.

\section{Pemeriksaan tahap pertama dan pemeriksaan tahap kedua \\ Pada pemeriksaan kesehatan haji} tahap pertama dan tahap kedua dilakukan sebelum keberangkatan jemaah haji. Seluruh puskesmas di Surabaya setelah mendapatkan data mengenai jemaah yang akan berangkat ke Tanah Suci mengundang jemaah untuk melakukan pemeriksaan. Pemeriksaan tahap pertama dilaksanakan tiga bulan sebelum keberangkatan yaitu tanggal 7 April dan pemeriksaan tahap kedua dilaksanakan satu bulan sebelum keberangkatan yang dilaksanakan serentak di Puskesmas Surabaya yaitu tanggal 4-14 Agustus 2015. Ketepatan waktu mengacu pada seberapa cepat data dikelola dalam seluruh sistem surveilans dan berapa banyak waktu yang dibutuhkan di masing-masing langkah proses (Klaucke, 1992)

\section{Pelaporan data}

Pelaporan data yang dilakukan puskesmas melalui aplikasi siskohatkes. Ketepatan waktu pelaporan di Dinkes Kota Surabaya mencapai 91,6\%. Ketepatan waktu pelaporan di Dinkes Kota Surabaya memiliki target sebesar $80 \%$, sehingga ketepatan waktu pelaporan sudah mencapai target yang di tetapkan oleh Dinkes Kota Surabaya. Ketepatan waktu juga dinilai dengan jarak antara kejadian suatu peristiwa kesehatan dengan pengiriman laporan kepada pelayan kesehatan, identifikasi wabah dan pelaksanaan pengendalian penyakit berdasarkan laporan tersebut (Klaucke, 1992).

\section{Analisis, interpretasi data dan diseminasi informasi}

Hasil penelitian menunjukkan analisis dan interpretasi data telah dilakukan setelah data telah terkumpul seluruhnya. Hasil analisis dan interpretasi disebarluaskan kepada atasan dan walikota. Dalam menilai ketepatan waktu juga mempertimbangkan waktu yang dibutuhkan dalam proses pelaporan kepada organisasi kesehatan yang bertanggung jawab dalam memberikan upaya pencegahan dan penanggulangan penyakit atau masalah kesehatan (Magnus, 2008).

Faktor yang mempengaruhi ketepatan waktu adalah waktu pelaporan hasil laboratorium kepada dokter atau instansi kesehatan masyarakat, waktu yang dibutuhkan dokter dalam pelaporan kasus kepada instansi kesehatan masyarakat, waktu yang dibutuhkan dalam mengidentifikasi tren, KLB. Faktor yang mempengaruhi proses identifikasi adalah kesederhanaan dan penyampaian kejadian yang berhubungan dengan kesehatan, susunan kepegawaian dari instasi kesehatan dan hubungan antara instansi kesehatan dengan organisasi (CDC, 2001).

\section{Evaluasi Sistem Surveilans Kesehatan Haji di DinkesKota Surabaya Tahun 2015 berdasarkan Atribut Stabilitas}

Sistem surveilans kesehatan haji di DinkesKota Surabaya sudah menggunakan sistem komputer dengan aplikasi siskohatkes yang memudahkan dalam memasukkan data, editing, menyimpan, dan back-up data. Sistem komputer dengan aplikasi siskohatkes menjadi data terkumpul, terkelola, teratur, tersimpan dengan baik dan mudah dioperasikan jika sewaktu waktu dibutuhkan. Namun pada tahun 2015 aplikasi siskohatkes yang digunakan dalam sistem surveilans pernah mengalami masalah yaitu tidak dapat diakses selama 2 minggu. Oleh karena itu, sistem surveilans kesehatan haji di Dinkes Kota Surabaya belum memenuhi atribut stabilitas. 
Suatu sistem surveilans yang memiliki sifat stabilitas memiliki sifat reliabilitas tinggi yaitu data terkumpul, terkelola, teratur, tersimpan tanpa kecacatan dan memiliki sifat availabilitas tinggi yaitu mudah untuk dioperasikan ketika dibutuhkan (CDC, 2001).

Pengukuran atribut stabilitas dalam sistem surveilans dilakukan melalui jumlah kejadian yang tidak terjadwal sebelumnya dalam kegiatan yang berhubungan dengan data dan informasi misalnya kerusakan komputer, biaya yang dikeluarkan dalam mengatasi permasalahan sistem, persentase waktu sistem berjalan secara penuh, waktu yang dibutuhkan sistem untuk mengumpulkan dan menerima data, dan waktu yang dibutuhkan sistem untuk melakukan manajemen data meliputi transfer, entry, editing, menyimpan dan back up data (CDC, 2001).

\section{SIMPULAN}

Penilaian terhadap atribut surveilans menunjukan bahwa sistem surveilans kesehatan haji di Dinkes Kota Surabaya tahun 2015 dapat memenuhi atribut fleksibilitas, ketepatan waktu, sensitifitas, akseptabilitas dan kerepresentatifan. Penilaian terhadap atribut surveilans menunjukkan bahwa sistem surveilans kesehatan haji di Dinkes Kota Surabaya tahun 2015 belum dapat memenuhi atribut kesederhanaan, kualitas data dan stabilitas, sedangkan penilaian atribut nilai prediktif positif tidak dapat dihitung.

Dinkes Kota Surabaya melakukan pemantauan secara periodik mengenai pelaporan data yang dilakukan puskesmas agar mengetahui puskesmas mana yang pelaporan datanya belum tepat waktu sehingga dapat diberikan saran perbaikan, Dinkes Kota Surabaya bekerja sama dengan KBIH se Kota Surabaya untuk mensosialisasikan manfaat dari pemeriksaan kesehatan jemaah haji sehingga diharapkan jemaah dapat dilaksanakan tepat waktu, Dinkes Kota Surabaya melakukan pelatihan kepada tenaga surveilans kesehatan haji mengenai surveilans kesehatan haji dan dilengkapi literatur tentang surveilans kesehatan haji. Selain itu petugas yang sudah mendapatkan pelatihan diwajibkan untuk membagikan hasil pelatihan kepada petugas surveilans kesehatan haji lainnya dan membuat jadwal rencana pemeriksaan jemaah haji agar pemeriksaan tidak bersamaan dengan pasien umum dan beban kerja dokter dan perawat menjadi lebih ringan.

\section{DAFTAR PUSTAKA}

Centers For Disease Control (CDC). 2001. Updated Guidelines for Evaluating Public Health Surveillance System. MMWR, 50(RR-13).

Dinkes Provinsi Jawa Timur. 2014. Penyelenggaraan Kesehatan Haji Provinsi Jawa Timur 2012-2014. Surabaya: Dinkes Provinsi Jawa Timur.

Kementerian Kesehatan RI. 2011. Pedoman Teknis Pemeriksaan Kesehatan Jemaah Haji. Jakarta: Kementrian Kesehatan RI.

Peraturan Menteri Tenaga Kerja dan Transmigrasi Republik Indonesia Nomor 8 Tahun 2004 Tentang Pedoman Penyelenggaraan Pelatihan Berbasis Kompetensi. Jakarta: Kementrian Tenaga Kerja dan Transmigrasi.

Keputusan Menteri Kesehatan Republik Indonesia Nomor 442 Tahun 2009 Tentang Pedoman Penyelenggaraan Kesehatan Haji Indonesia. Jakarta: Kementrian Kesehatan.

Klaucke, D.N. 1992. Evaluating Public Health Surveillance Systems. United States: Library of Congress.

Magnus, M. 2008. Buku Ajar: Epidemiologi Penyakit Menular. Jakarta: Kedokteran EGC

Nazir, M. 1988. Metode Penelitian. Darussalam: Ghalia Indonesia.

Noor, N.N. 2008. Epidemiologi. Jakarta: PT Rineka Cipta.

Peraturan Menteri Kesehatan Republik Indonesia Nomor 45 Tahun 2014 Tentang Penyelenggaraan Surveilans Kesehatan. Jakarta: Kementrian Kesehatan. 